\title{
Nesor Annim, Niteikapar (Good \\ Morning, Cardinal Honeyeater): \\ Indigenous Reflections on Micronesian \\ Women and the Environment
}

Myjolynne Marie Kim

\author{
Kapasen Tirow: Opening Prayer \\ Tirow Náang (I bow to the Heavens) \\ Tirow Fénú (I bow to the Land) \\ Tirow Mataw (I bow to the Seas) \\ Tirow Aramas, Tirow (I bow to the People $)^{1}$
}

\begin{abstract}
As
s a Chuukese Islander, I begin this paper with a customary tribute to acknowledge and honor the skies, land, and ocean and all those who dwell in these realms. This acknowledgement reveals the importance and sacredness of the environment and the deep relationship Chuukese people have with their environment and surroundings, reminiscent of Paul D'Arcy's reminder that in the Pacific world "all things were connected" $(2006,36)$. This integral, intimate relationship continues to this day.

In Chuuk, an island archipelago in Micronesia (map I), the environment is life and connects human, nonhuman, and spirit beings. It encompasses nááng (skies), mataw (ocean), and fénú (land) and is esteemed as manaman (sacred), alive, and motherly. The environment bears life just as a woman bears life. In Chuukese ontology and structures of feeling, we are all connected through maternal creation. As mothers, women embody the environment, making visible in human domains its broader role in giving birth to all living things, human and nonhuman, spirits and non-spirits.

The consubstantiality of the environment and mothers is rooted in Chuukese cosmology and stories of creation or origin, including those around Nikoupwupw Fénú, bearer of the islands, who gave birth to the
\end{abstract}

The Contemporary Pacific, Volume 32, Number I, I47-I 63

(C) 2020 by University of Hawai'i Press 
islands, the people, and all its creatures (Dobbin 20II; Goodenough 2002; Hofmann 2017). The literal translation of nikoupwupw fénú is "the breast that feeds the land," which captures the significant role of women as mothers (iin) and as procreators of life. Stories around the goddess invoke the vitality of each woman's role and responsibility toward the land as environment and the centrality of maternal identity within Chuuk's strong matrilineal culture, which determines one's ancestry and access to leadership, inheritance, and Indigenous knowledge. Such contexts reveal how Chuukese culture regards women as mothers with a customary responsibility to care for, nurture, and protect both the affairs of the people and the environment that provides for them.

In this article, I consider the importance of Chuukese women as nikoupwupw fénu, which speaks to their customary role as mothers and as custodians of the environment-a potent identity across Micronesia. I trace the roots of female leadership in and across Micronesia to their cosmologies and matrilinealities, and I suggest that the challenges confronting matrilineal leadership are linked to the destruction of the environment brought forward by colonialism, militarism, and capitalism (see Gewertz and Errington; Mel; Smith, this issue). I then turn to contemporary women's environmental and political activism in Chuuk and beyond. Empowered by Chuukese and Micronesian women activists, I explore

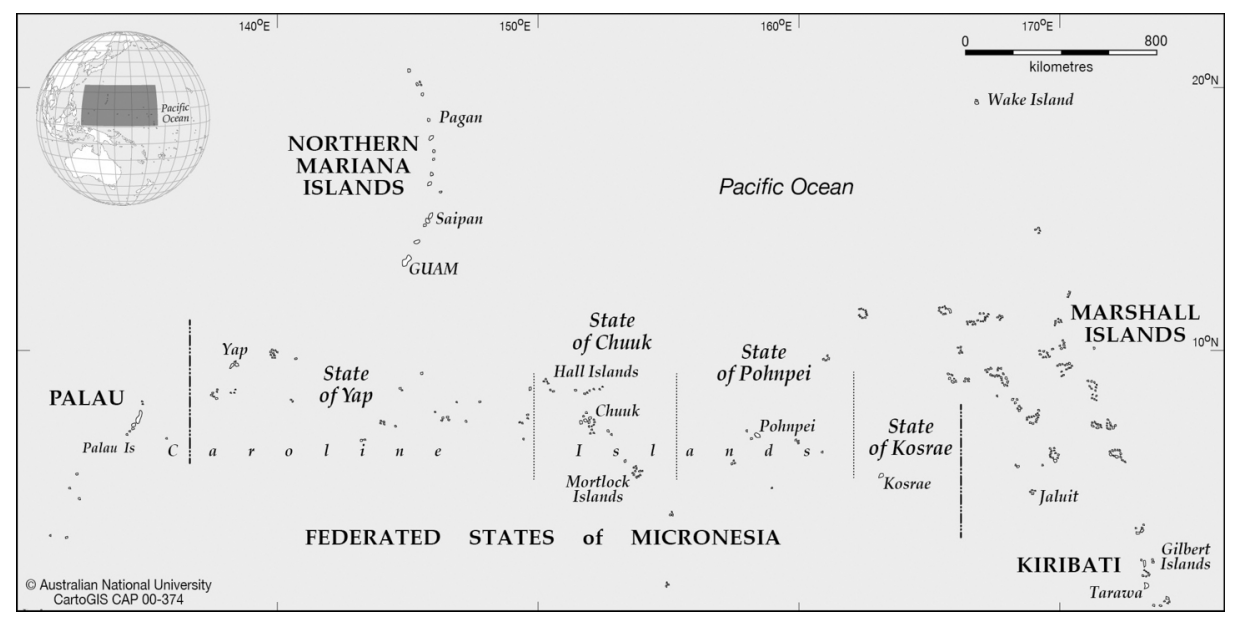

Map I Map of the Federated States of Micronesia. Copyright the Australian National University, College of Asia and the Pacific, CartoGIS. Reproduced with permission. 
the concept of environmental leadership through Indigenous perceptions of motherhood as a platform and pathway to reengage and reawaken women's leadership in matrilineal Micronesia. I write this article from my position as a Chuukese woman and a mother-personally, politically, and academically.

Although Chuukese people continue to recognize the fundamental social role of women, a political government that is predominantly male and embodies patriarchal values has now practically displaced and erased the powerful positions Chuukese women customarily held. The impacts of four different successive colonial powers (Spain, Germany, Japan, and the United States), along with Christian missionaries, led to social changes that disrupted matrilineal values and privileged male power. Father Francis Hezel, well-known for his extensive work and research in Micronesia, claimed that "the general absence of women from these public leadership positions can be traced back to the principle division of labor in the islands" (2OI3, I23). In precolonial times, complementary gender roles existed in which men held authority in public spaces and women held authority behind the scenes (Hezel 20I3, I23-I24). These different but complementary gender-defined roles were crucial to social dynamics. He noted, "Outward appearances to the contrary, women have always enjoyed authority and respect in the island cultures of Micronesia.... It is no exaggeration to state that in the matrilineal society of the islands the social edifice was built on the foundation of women. Women were the custodians of the land, the anchor of the family, providing continuity in the home and the community" (Hezel 2013, II6). Today, as owners and custodians of the land, women still have political power and are important decision makers in some families and kin networks. A close relative shared with me the importance of women in decision making within her extended family. For example, when one of her uncles passed away, his uncles and the government planned funeral proceedings. Yet no decisions were made without consulting with the women of the clan. It was the women who made the final calls on the arrangements. Chuukese women thus play a significant part in decision making even though it is not always evident and visible to the public eye.

Anthropologist Beatriz Moral suggested that women's silence and behind-the-scene roles were necessary in the limited space of atoll life in order to maintain the incest taboo between brother and sister, who had to avoid each other's physical presence (I998). This was also pointed out in a conversation I had with an elder. She explained that women's silence 
has nothing to do with gendered inferiority or superiority. Rather, the aim is to maintain harmony within social family structures, often through reciprocal gestures of respect between a brother and a sister that are often misunderstood by some Chuukese Islanders and foreign visitors. Traditionally, it is taboo for a brother and a sister to be alone in the same space. If this happens, they could be disowned by their family and relocated. She further explained to me that this is how several Chuukese clans in history had separated from their original clans: individuals had broken this incest taboo and felt obliged to leave.

Later in history, the US colonial government introduced parliamentary democracy. ${ }^{2}$ While democratic in outlook, this type of political government privileged men's public representation and a Western educational system. Both devalued the power of Chuukese women as guardians and transmitters of Indigenous knowledge and practices (Moral 1998). Such changes weakened and shifted women's role in their matrilineal societies. As a result, through the lens of foreign visitors, Chuukese women's public silence appeared to be a sign of their inferiority. Thus, anthropological writings and other scholarly literature mostly continue to describe Chuukese women as submissive, quiet, and inferior-an image that has become visibly predominant in writings about Chuuk and embodied by more recent generations.

Despite these challenges, Chuukese women keep mobilizing for positive changes in their society, be it politically, socially, or environmentally. They are organized in local and national women's groups. The Chuuk Women's Council, an umbrella organization for women's groups, remains a prominent advocate for a healthy environment and sustainable future in areas such as waste management, home gardening, and mangrove planting. In Chuuk, many women joke that perhaps women should manage the government offices for public affairs, the environment, transportation, and tourism. Such jokes mask a real frustration behind these remarks regarding the failure to translate traditional cultural roles into political power within contemporary government.

\section{Motherhood And Cosmologies in Micronesia}

I was thirty years old when I became pregnant. The initial stage of my pregnancy was hard to bear, characterized by nausea, extreme fatigue, sleepless nights, and irregular pains. Even worse, I was pregnant out of wedlock, which, in Chuukese culture was a dishonor and disgrace. I 
feared stigma, shame, and humiliation, especially toward and from my family. I kept replaying such thoughts as: How was I supposed to share the news? Would my family disown me? How would they bear the shame? Would our society humiliate them because of what had happened to me? Just as I had anticipated, my family was quite upset, and by then it was looking like I would end up a single parent. But a good friend of mine reassured me, "Your family will be angry now, but be patient. Everything will change once they see and hold the baby." She was right.

I gave birth to my son in Vancouver, Washington, while visiting my sister. I was in labor for over twenty-four hours when the midwives and nurses advised me to consider a cesarean section. Stubborn with pride, I refused, claiming I was strong enough and determined. Then my father told me over the phone, "Mymy, you're only thinking of yourself. Think of the baby." I realized that I was so absorbed in my own pain that I had not considered the life I was about to bear. After I hung up, I looked at the nurses and said, "Alright, let me sign the papers." That very night I gave birth to my son, Rong.

Becoming a mother was a complicated, painful, and discomforting experience, yet it was one of the most beautiful experiences in my life. Most importantly, I have given birth to the land. I share this personal story because becoming a mother for me has evoked deeper insights into a shared responsibility toward the environment-that which provides for us. It has infused in me a deep conscientiousness of the environment into which my son has been born, and I feel committed to ensuring that he has a safe upbringing and future. Furthermore, I can now relate to women elders in Chuuk and across Micronesia as social justice and environmental leaders. Their identity as mothers gives them the platform and position to protect the environment and safeguard it for generations.

I have a vivid recollection of a conversation with a Chuukese elder uncle who once told me, "Do not underestimate the power of women. Chuukese women are so important and special because they give life." As a young Chuukese woman with a Western education, I brushed this off as another cliché. But deep down inside of me, it made me wonder. As time went by, and especially after the passing of this uncle, the remark kept haunting my thoughts to the point that it motivated me to undertake my $\mathrm{PhD}$ research on Chuukese women. What he said is starting to make sense now; after twelve years, I am finally beginning to understand its depth of meaning. Another elder explained to me that the most important role for a woman in Chuuk is nikoupwupw fénú. In the Chuukese language, to give birth is 
translated as oupwu or oupwatiw, meaning "to breastfeed." Breastfeeding conveys that, in Chuukese culture and society, women are mothers and hold the responsibility to nurture, care for, and provide for their children and broader community. As mothers, women also care for the environment, and the environment "feeds" or provides for them.

It is important to note that a woman does not have to be a biological mother to be considered a mother and to fulfill customary maternal responsibilities. The Chuukese word for family is iinneupwinneu, or, to break down the words, iin-neu-pwiin-neu, translated as "mother-daughter-sister-daughter" (Higashi 2008). Anthropologists Per Hage and Jeffrey Marck noted that the terms for parents in a Proto-Micronesian kinship system were the same for, or were extended to, the siblings of the parents, just as the terms for siblings were extended to cousins (2002). In the Chuukese language, there is no word for "aunt" because in the classificatory kinship system, an aunt is considered equivalent to a mother or iin or iinenap (great mother). Therefore, the Chuukese concept of iinenap (motherhood) is not limited to the biological definition of a mother or to one who has physically given birth to a child; rather, is inclusive of women elders within the family or clan. For this reason, women generally are expected to carry out the same maternal responsibilities or provide the same care for everyone in their family or clan.

As articulated earlier, the sociocultural identity of women as mothers is rooted in Chuukese cosmology and oral traditions. Nikoupwupw Fénú, the eternal goddess, materialized as a coconut and gave birth to the first people of Chuuk, thus becoming the procreator of the islands of Chuuk (Goodenough 2002, I99; Dobbin 20II). In some versions, she is a coconut palm (which refers to or symbolizes a woman in Chuukese oral traditions), but she is generally accepted in oral history as the origin and mother of the Chuukese people. In Chuukese itang (historical lore), Nikoupwupw Fénú (sometimes referred to as the wife or sister of Anunap, the great sky god) created the three largest islands: Tol, Weno, and Fefen. Around these, she created a great ring of coral to protect the islands from gigantic waves. Making sure that the islands were well protected and sheltered, she scattered smaller islands within and outside of this coral reef. Birds, insects, and all different kinds of marine life were created and situated on the land and in the sea. Last, she created and gave birth to the first people to protect all she had created (Goodenough 2002).

Because Chuuk emerged from a woman's nurturing breast, the identity of mother is central to Chuukese matrilineal culture. Within the matrilin- 
eal system, women hold significant power, as they determine one's ancestry, which is traced through the female kinship clan. They are the primary owners of and decision makers regarding customary land. Matrilineal kinship determines one's access to Indigenous knowledge, land rights, and Indigenous leadership or chiefly status (Kim 2007).

This foundational role of women is also conveyed through Chuukese cultural practices, lore, and cosmology. For instance, there are two complementary Chuukese conservation practices, called pwaú (land conservation, which takes place on the land) and mechen (sea conservation, which takes place in the reef), that are carried out by a clan or family member after a person's passing (Goodenough 2002; Kim 2007). According to one Chuukese elder, it used to be women who were responsible for initiating, organizing, and carrying out mechen or pwau, but nowadays men call for them. Over centuries of colonial rule, many such matrilineal practices and values were replaced by a patriarchal system, and what used to be women's responsibilities have either been alienated or become blurred in a male-dominated society.

\section{These Islands Belong to Women}

The connection between the environment and motherhood is not distinctly exclusive to Chuuk. It extends across Micronesia and elsewhere in Oceania. Local stories throughout Micronesia similarly assert a fundamental relationship between maternal identities and the environment. For instance, in Pohnpeian oral history, a stingray is considered nobno en sed, the "ocean mother," for its role in assisting humans in safe childbirth (Carl 20I8). Alongside Chuukese cosmology, oral histories of Guam and Palau reveal capable foundational roles for a female bearer or creator of their landscapes.

The birth of Guam is attributed to Putan and his sister Fuuna. Long before the creation of the earth and sky, Putan and Fuuna were omnipotent beings. Putan felt that his death was approaching, so he called Fuuna to him and transferred all his powers to her. He instructed her to divide and dispose of his remains after his death: his eyes shall become the sun and the moon, his breast shall become the sky, and the rest of his body parts shall become different parts of the world. When Putan died, Fuuna carried out her brother's wishes, and the world was created. In awe of the beauty of the world, she decided to create human beings in her image. Drawing together all the elements of the earth and sea, she transformed 
herself into a seagirt isle of many great stones. She gave them life and thus gave birth to the first people of Guåhan, known today as Guam (SouderJaffery I992).

Similarly, in Belauan cosmology, the current landscape of Belau (the largest island of Palau) ${ }^{3}$ was created from the body parts of Chuab, a female demigod. She became a giant from overeating. Every day the Islanders would bring food to Chuab. But because Chuab could not stop eating, this became a burden to the people and their resources, so they agreed to engulf her in fire. Her body parts then created the island of Belau. Some oral stories claim that Chuab was aware of the scheme to have her killed and sacrificed her body for the people of Belau (Flood, Strong, and Flood I999).

These creation stories reveal the importance of Micronesian women in their respective precolonial societies. Today, matrilineal kinship systems exist across the region in which women own and inherit land. Matrilineal societies can be found in Palau, the Marianas archipelago, the Caroline Islands, the Marshall Islands, and some parts of Kiribati (Souder-Jaffery I992; T Teaiwa I992; Hezel 2013; Hofmann 2015). As discussed earlier, Micronesian women customarily held strong positions and decision-making powers over land rights and land use, transfer, distribution, and custody. I suggest that the creation stories are salutary and, together with a matrilineal kinship system and an emphasis on motherhood, form the foundation for the ongoing political and environmental activism of Micronesian women and their communities.

At the Micronesian Women's Conference in Majuro in August 20I7, Dr Hilda Heine, President of the Marshall Islands, conveyed in her opening statement that "these islands belong to women." In the same statement, she further claimed that Marshallese women as mothers are responsible for the well-being of their families, their clans, and the nation. An example of women's engagement with environmental destruction can be seen in neighboring Banaba (Ocean Island) in Kiribati. Katerina Teaiwa noted that Banaba Islanders describe their island as "te aba n aine," which means "the women's land" (20I4, I33). When the British Phosphate Commission came to Banaba for phosphate mining, Banaban women were the ones who clung to the trees and protested against the transfer of the land to the phosphate mining companies: "Women, especially owners within the proposed new area, [are] arbitrarily and blindly opposed at present to transfer of land under any conditions whatever" (MacDonald 200I, I07; see K Teaiwa 20I4, I33). 


\section{Micronesian Women's Activism and Resistance}

While women are mostly absent from the public political space of official government, they are prominent as environmental and political activists, reconnecting to their historical roles as guardians of the environment and society. Dé Ishtar's Daughters of the Pacific emphasizes that, as landowners, Pacific women regard themselves as strong advocates for the land (I 994). As Pacific environments are challenged by militarism, colonialism, economic development, and climate change, women are at the front line, advocating for a safe and sustainable environment (dé Ishtar 1994). This is also the case in other parts of the world. Dé Ishtar highlighted a quote from a Navajo woman, Lenora Hill Diné, on the role of women and the protection of the land, which resonates well with Micronesia: "We see that the destruction of Mother Earth is the destruction of women. We have the responsibility as women, the givers of life, to make sure that that destruction does not continue" ( I994, I I).

"The rape of Oceania began with Guam," wrote Douglas Oliver in his history of the Pacific (1989, 234), referring to the first European encounter with the Pacific by Magellan, who accidentally stumbled on Guam in I 52I. As in other Pacific places, Micronesia's environment has endured centuries of destruction due to foreign traders extracting resources such as bêche-de-mere (sea cucumbers) (Hezel I995, I979; Kim 2007; see Gewertz and Errington, this issue). We were ambivalent hosts to numerous catastrophic foreign battles during World War II. But the most notable and, as the late Pacific studies champion Teresia Teaiwa argued, the "most dangerous" effect on the islands was and still is militarization (I992, I26). After World War II, the United States took trusteeship of Micronesia (with the exception of Nauru and Kiribati), which was deemed important for its strategic location and for US military expansion. During the Cold War, the region remained significant for similar reasons. Guam currently hosts the largest military base between the United States and Asia, and this has subjected the islands and their inhabitants to further abuse and destruction, with a devastating effect on communities, particularly on women as mothers and landowners (T Teaiwa I992).

Between 1946 and 1958 , the United States detonated sixty-six nuclear bombs in the Marshall Islands, with enduring destructive consequences for the people and their environment (dé Ishtar 1994), including severe health issues and the continuing displacement of many Marshall Islanders. Exposure to the nuclear radiation led to burns on the skin, hair loss, vom- 
iting and diarrhea, and cancer. Women also experienced extreme pregnancy complications, with frequent miscarriages and birth defects among newborn and stillborn babies. Islanders continue to suffer from prolonged effects of exposure to radioactivity, which extend even to their descendants. Their islands were severely contaminated by the nuclear waste and are permanently uninhabitable (Barker 20I2; Johnson 20I3).

The late Darlene Keju-Johnson was a Marshallese activist well known for her 1983 speech before a global church audience in Vancouver, British Columbia, at the Pacific Plenary of the World Council of Churches Assembly. There she spoke of the many hidden stories of the Marshall Islanders who became victims of nuclear testing and radiation. She exposed major health consequences such as cancer and the constantly increasing rate of stillbirths, and she revealed to the world that many Marshallese women were giving birth to "jellyfish" babies-that is, babies with severe birth defects. She brought the world's attention to Marshall Islanders' suffering due to nuclear testing, and she made known many local narratives and realities that were not acknowledged by the US government. The US military eventually shut down the nuclear base and missile testing, but it had already created severe environmental and health impacts. Keju-Johnson was also notable for her advocacy of Marshall Islanders' access to healthcare programs and health-care assistance (Johnson 20I3).

As mothers and custodians of the environment, Micronesian women were at the forefront of resistance to and protest against the militarization of the region. Chamoru woman activist Chailang Palacios declared, "We are the people of the land and the ocean and we are struggling for survival. The ocean is our spirit. We come back, we sit down, we cry, we pray, we are still praying. Because our water is killing us, slowly. It has been polluted since World War II and since the nuclear bombs" (WwNFIP I987, I4). Chamoru women have led their communities in the face of such social changes. In their matrilineal society, Chamoru women historically held positions of power and remain a strong influence for change. They continue to affect decisions over land and play a central role in teaching Indigenous language, culture, values, and practices within their families (Poehlman 1979). The pattera, or Chamoru midwives, were influential in rupturing US Navy regulations that were intended to eliminate Indigenous health practices and that undermined Chamoru women (Hattori 2004). Chamoru scholar Christine (Tina) Taitano DeLisle turned to the pattera practice of burying the placenta in the soil to recognize the importance of women's connection to and stewardship over the land to explain the 
history of Chamoru women's resistance against the military occupation of Chamoru land (2015). Drawing from pattera resistance, she coined the term "placental politics," a native-inspired theory guided by Chamoru women's stewardship over their land and their ongoing struggle to resist military use of native land (see Frain 2017, I32). With their long history of activism and resistance, Chamoru women continue to direct efforts to protect their environment. When Japan announced that it would dump fifty thousand barrels of nuclear waste annually into the Marianas Trench, Chamoru women were on the front line of the ultimately successful campaign to thwart the plan. Under the London Dumping Convention of 1993 , more than forty countries agreed to ban nuclear and industrial dumping into the sea (dé Ishtar 1994).

Meanwhile, in Western Micronesia, Palau witnessed the horrific impact of nuclear testing on the Marshall Islands. In I979, as a response to the man-made nuclear disasters and US imperialism in the region and under the influence of strong women leaders and activists, matrilineal Palau became the first nation in the world to vote for a nuclear-free constitution (by 92 percent). The document includes a constitutional clause requiring a vote of 75 percent to allow for nuclear weapons to enter Palauan territory. Since Palauan people had also experienced firsthand the destruction caused by industrial warfare through World War II and suffered from environmental damage, they wanted no more foreign battles on their shores.

At the same time, negotiations between Palauan and US governments over a compact of free association were ongoing. This compact would have granted the United States control over land rights for national or military interests in exchange for economic support to Palau. The antinuclear clause, however, created a conflict with the United States' interest to expand its military bases on Palau. With this clause in the constitution, the United States refused to sign the compact, demanding that Palau drop the clause and related provisions in order to enter into a treaty. While a majority of the all-male politicians of Palau were willing to do so, the women leaders stood their ground and successfully prevented the change to the constitution.

This resistance was a women's campaign. Under the leadership of the late Mirair Gabriela Ngirmang, the highest-ranking woman of Koror at the time, Palauan women mobilized to educate the communities, the villages, and the greater population in understanding the importance of a nuclear-free Palau. In 1987, the Palauan government (ie, male politicians) attempted to amend the clause to allow constitutional changes with only a 
simple majority. Ngirmang mobilized a group of fifty mothers and filed a lawsuit against the Palauan government. However, this action endangered their lives: gunshots were fired at their houses, and Ngirmang's home was firebombed. Even the police ordered the women to drop their lawsuit.

Between I979 and I993, the constitutional antinuclear clause was voted on eleven times. In the end, the Government of Palau amended the clause to require only 50 percent of the vote in order to change constitutional law and ensure economic assistance from the United States (dé Ishtar 1994). The Palauan women struggled with their own government to keep Palau nuclear-free and to ensure that the people and their environment would be secured from the dangers of nuclear weapons (dé Ishtar I994). The Palau women's organization Otil A Beluad was nominated for the Nobel Peace Prize in 1988, and Ngirmang was nominated in 2005 (dé Ishtar 2008). In her own words, Ngirmang explained that "in Palau [Belau] women play an important role in issues of policy. Women traditionally own land. We control the clan money. We traditionally select our chiefs-women place and remove them" (quoted in dé Ishtar 1994, 43).

\section{Conclusion: Nesor Annim, Niteikapar}

As I have shown, women's activism across Micronesia is linked to their matrilineal leadership and their cultural identity as mothers. Although many factors have contributed to the demise of matrilineal leadership, linkages between the destruction of the environment, militarism, and colonialism have been major contributors to the decline of women's status in their societies. Regardless, Micronesian women continue to mobilize and advocate for their Indigenous rights and homes.

These stories of Micronesian goddesses and women activists in the past and present empower me and serve as an inspiration for women to further advance gender empowerment in our respective societies. Reflecting on early cosmologies, oral traditions, and the significant power of women, I use a Chuukese greeting I learned from an elder, nesor annim, niteikapar (good morning, cardinal honeyeater), which refers to the awakening of the early dawn and of a new day.

This greeting is significant for me because it reveals the important and close relationships between people and their environment. It conveys the deep and meaningful connections people historically have had with their environments (see Ballard; Evans, this issue). I employ this greeting as a calling, an awakening, and a reminder of the significant power women had in their precolonial societies and of the fact that their representation 
in contemporary decision making is culturally appropriate. I use this greeting to strongly encourage women to uphold their responsibility to protect their respective environments. To contaminate and destroy the environment is to degrade women and undermine their potency and fundamental position in society.

The customary perspective of motherhood and its role to safeguard the environment offers a pathway to empower women's voices, participation, and leadership. Environmental activism is important to Micronesian women as mothers, as they carry the responsibility of caring for the environment, the land, and the people. But I also see environmental activism as a platform that allows all Micronesian women, in a male-dominated political space, to be vocal and empowered. It compels a male-dominated society to be receptive to women's participation in decision making. Further research in this area is needed to explore how we can utilize women's environmental leadership to provide pathways for gender equity.

As a Chuukese woman and mother, I am optimistic about the future of Micronesian women because this reawakening of maternal leadership involves an intergenerational initiative of Micronesian elders and youth. At a United Nations assembly in New York in September 20I4, the young Marshallese poet Kathy Jetn̄il-Kijiner delivered her poem "Dear Matefele Peinam," which she addressed to her daughter, assuring and promising that she would fight for her:

\author{
Dear Matefele Peinam \\ Don't cry \\ Mommy promises you \\ No one \\ Will come and devour you \\ No greedy whale of a company sharking through political seas \\ No backwater bullying of businesses with broken morals \\ No blindfolded bureaucracies gonna push \\ This mother ocean over \\ The edge... \\ Because baby we are going to fight \\ Your mommy daddy \\ Bubu jimma your country and president too (Jetñil-Kijiner 20I4)
}

Her poem reminds me that I, a mother, am not alone in my concern and advocacy for a sustainable and safe environment. The role of Micronesian women as mothers is important and serves as a guiding path for gender leadership and equity. In the words of Chamoru activist Maria Pange- 
linan, "Nobody will do it for us unless we do it" (WWNFIP I987, 28). No one will care for the land, the people, and the environment if we as women leaders do not care for it. It is up to us.

THIS ARTICle WAS PART OF A KeYNOTE ADdRess at the 20 I7 European Society for Oceanists conference in Munich, Germany. I want to thank the conference's organizers, Eveline Dürr, Philipp Schorch, Sina Emde, and Rebecca Hofmann, for their invitation and for editing the article. I also want to thank Paul D'Arcy, Vicki Luker, Zag Puas, Joakim Jojo Peter, Nic Halter, and George Carter for shaping the ideas behind it. This article would not have been possible without deep discussions with the Chunkese people.

\section{Notes}

I This is a Chuukese honorific tribute of humbling oneself in acknowledging, honoring, and respecting one another and the surrounding environment. It is also used as a greeting or tribute to seek forgiveness and ask for blessings. Here, I use the words as a prayer to seek blessings and forgiveness from my elders, ancestors, and the spirits of knowledge. The phrases of this greeting can vary from one context to another, but I have employed some phrases from L J Rayphand's English translation (2014, I4).

2 Political governments across Micronesia (Palau, the Federated States of Micronesia, and the Republic of the Marshall Islands) are fashioned after the US political system.

3 I learned from some Palauan Islanders that while Belau is the accurate name of the island, the name Palau is used to be inclusive of the outlying islands that have different linguistic and cultural backgrounds from Belau.

\section{References}

Barker, Holly

20I2 Bravo for the Marshallese: Regaining Control in a Post-Nuclear, Post-Colonial World. Belmont, CA: Thomson/Wadsworth.

Carl, Carol Ann

2018 Nohno en Nansed: The Pohnpeian Story of Childbirth. Keweriwer (blog), 25 July. https://keweriwer.wordpress.com/2018/07/25/nohno -en-nansed-the-pohnpeian-story-of-birth/ [accessed 7 June 2019]

D'Arcy, Paul

2006 Significant Spaces: The Role of Marine Ecosystems in Pacific Island Cultures. Transforming Cultures eJournal I (2): 34-43. 
dé Ishtar, Zohl

I994 Daughters of the Pacific. Melbourne: Spinifex Press.

2008 Celebrating the Life of Gabriela Ngirmang of Palau (Belau). Capitalism Nature Socialism I9 (I): I4 I-I44.

DeLisle, Christine Taitano

2015 A History of Chamorro Nurse-Midwives in Guam and a "Placental Politics" for Indigenous Feminism. Intersections: Gender and Sexu-

Dobbin, Jay D ality in Asia and the Pacific 37.

$20 \mathrm{I}$ Summoning the Powers Beyond: Traditional Religions in Micronesia. Honolulu: University of Hawai'i Press.

Flood, Bo, Beret E Strong, and William Flood

I999 Pacific Island Legends: Tales from Micronesia, Melanesia, Polynesia, and Australia. Honolulu: Bess Press.

Frain, Sylvia

2017 Fanohge Famalå'an \& Fan'tachu Fama'lauan: Women Rising Indigenous Resistance to Militarization in the Marianas Archipelago. Dunedin: University of Otago.

Goodenough, Ward Hunt

2002 Under Heaven's Brow: Pre-Christian Religious Tradition in Chuuk. Memoirs of the American Philosophical Society 246. Philadelphia: American Philosophical Society.

Hage, Per, and Jeff Marck

2002 Proto-Micronesian Kin Terms, Descent Groups, and Interisland Voyaging. Oceanic Linguistics 4I (I): I 59-I70.

Haglelgam, John R

20I I Federated States of Micronesia in Review: Issues and Events, I July 2009 to 30 June 20I0. The Contemporary Pacific 23 (I): I72-207.

Hattori, Anne Perez

2004 Colonial Dis-Ease: US Navy Health Policies and the Chamorros of Guam, I898-I94I. Pacific Islands Monograph Series I9. Honolulu: Center for Pacific Islands Studies and University of Hawai'i Press.

Heine, Hilda C

2017 Statement by President Dr. Hilda C. Heine. Navigating Change: Micronesian Women's Conference Opening Ceremony. Majuro, 8 August. http://rmi.micronesianwomensconference.spc.int/statement Hezel, Francis X -by-president-dr-hilda-c-heine/ [accessed 7 June 20I9]

I979 Foreign Ships in Micronesia: A Compendium of Ship Contacts with the Caroline and Marshall Islands, I52I-I885. Saipan, Mariana Islands: F X Hezel in cooperation with the Trust Territory Historic Preservation Office and the US Heritage Conservation and Recreation Service. 
I995 Strangers in Their Own Land: A Century of Colonial Rule in the Caroline and Marshall Islands. Pacific Islands Monograph Series I3. Honolulu: Center for Pacific Islands Studies and University of Hawai'i Press.

2013 Making Sense of Micronesia: The Logic of Pacific Island Culture. Honolulu: University of Hawai'i Press.

Higashi, Alton

2008 Getting to Know Chuuk. Third edition. Chuuk: College of Micronesia-Federated States of Micronesia, Chuuk Campus.

Hofmann, Rebecca

2015 The Puzzle of Chuukese Mobility Patterns: Contradictory, Dualistic, or Pluralistic? Anthropological Forum 25 (2): I3 I-I 47.

2017 Experiencing Environmental Dynamics in Chuuk, Micronesia. In Environmental Transformations and Cultural Responses: Ontologies, Discourses, and Practices in Oceania, edited by Eveline Dürr and Arno Pascht, 75-IOI. New York: Palgrave Macmillan US.

Jetn̄il-Kijiner, Kathy

2014 UN Climate Summit Poem “Dear Matafele Peinem.” Filmed September 2OI 4 at the UN Climate Summit. YouTube video, 3:I I. Uploaded 23 September. https://www.youtube.com/watch?v=DJuRjy9k7GA [accessed 7 June 2019]

Johnson, Giff

20I3 Don't Ever Whisper: Darlene Keju, Pacific Health Pioneer, Champion for Nuclear Survivors. North Charleston, sc: Createspace Independent Publishing Platform.

Kim, Myjolynne Marie

2007 Combatting "Dreaded Hogoleu": Re-Centering Local Histories and Stories of Chuukese Warfare. MA thesis, University of Hawai'i-Mānoa. MacDonald, Barrie

$200 \mathrm{I}$ Cinderellas of the Empire: Towards a History of Kiribati and Tuvalu. Canberra: ANU Press.

Moral, Beatriz

I998 Changes in Women's Status in Micronesia: An Anthropological Approach. In Indigenous Women: The Right to a Voice, edited by Diana Vinding, 65-74. IWgia Document 88. Copenhagen: International Work Group for Indigenous Affairs.

Oliver, Douglas L

I989 The Pacific Islands. Honolulu: University of Hawai'i Press.

Poehlman, Joanne

I979 Culture Change and Identity among Chamorro Women of Guam. PhD dissertation, University of Minnesota. 
Rayphand, L J

20 I Túúttúnnapen Chuuk: Retelling Chuukese Stories in the Digital Age. PhD dissertation, University of Hawai'i-Mānoa

Souder-Jaffery, Laura Marie Torres

I992 Daughters of the Island: Contemporary Chamorro Women Organizers on Guam. Second edition. MARC Monograph Series I. Lanham, MD: University Press of America and University of Guam.

Teaiwa, Katerina M

2014 Consuming Ocean Island: Stories of People and Phosphate from Banaba, Tracking Globalization. Bloomington: Indiana University Press.

Teaiwa, Teresia K

I992 Microwomen: US Colonialism and Micronesian Women Activists. In Pacific History: Papers from the 8th Pacific History Association Conference, edited by Donald H Rubenstein, I 25-I4I.

wWNFIP, Women Working for a Nuclear Free and Independent Pacific (Great Britain), editors

I987 Pacific Women Speak. Oxford: Green Line.

\section{Abstract}

Women across Oceania are social justice champions and advocates for Indigenous rights, political independence, anti-militarism, a nuclear-free Pacific, climate change justice, and gender equality. Recent studies have shown that Pacific women are empowered by their maternal responsibility to take a leadership role in protecting people, their resources, and the environment. To further expand on women's leadership role, I look into a deep Oceanic understanding of women and the environment, showing that Indigenous stories across Micronesia esteem the environment as sacred and maternal. Drawing on Indigenous stories of creation, I argue that Micronesian women historically held powerful status and prestige in their societies and that understanding maternal responsibility can be empowering and can advance gender equality, community resilience, and women's leadership in the contemporary Pacific.

KEYWORDs: Chuukese women, Micronesian women, Pacific environment, Chuukese/Micronesian cosmology, Micronesian women's activism and resistance 